\title{
THE HISTORICAL PERCEPTION OF THE TREATY OF TRIANON ON THE PAGES OF EDUCATIONAL TEXTS
}

\section{[HISTORICKE VNIMANIE TRIANONSKEJ ZMLUVY NA STRANKACH EDUKACNZCH TEXTOV]}

\author{
Martin Hetenyi - Adriana Kickova
}

doi: 10.18355/PG.2020.9.2.11

\begin{abstract}
The article presents the historical perception of the Treaty of Trianon from 1920 with emphasis on educational texts of (Czech-) Slovak textbooks. The attention of the authors is especially focused on the current state, which reflects the different perceiving of this subject in Slovakia compared to the perceptions of this topic in Hungary. Considering the close links between history didactics and historiography, the authors offer an insight on the subject's reflection in scientific circles, as well as an outline of possible outcomes and perspectives for presenting this differently perceived issue in history teaching as well as provide a platform for future historical research.
\end{abstract}

\section{Key words}

Slovak and Czech history textbooks, historical perception

\section{Abstrakt}

Príspevok predstavuje historické vnímanie Trianonskej zmluvy z roku $1920 \mathrm{~s}$ dôrazom na učebné texty (česko-slovenských učebníc. Pozornost' autorov sa osobitne zameriava na súčasný stav, ktorý odráža odlišné vnímanie tohto dokumentu na Slovensku v porovnaní s vnímaním dokumentu v Mad’arsku. Vzhl'adom na úzke väzby medzi didaktikou dejepisu a historiografiou ponúkajú autori pohl'ad na reflexiu dokumentu vo vedeckých kruhoch, ako aj náčrt možných výstupov a perspektív pre prezentáciu tohto rôzne vnímaného problému vo výučbe dejepisu. Zároveň poskytujú platformu pre budúci historický výskum.

\section{Kl'účové slová}

slovenské a české učebnice dejepisu, historické vnímanie

\section{Úvod}

Historickým údelom krajín a regiónov je zrod a zánik rôznych foriem štátnych zriadení. Jednou z posledných zásadných zmien v strednej Európe bola deštrukcia Rakúsko-Uhorska v roku 1918 a na jej základe prerod geopolitického usporiadania v podobe vzniku nových štátnych útvarov. Neuspokojivé riešenie požiadaviek všetkých národných a národnostných entít, ktoré žili v rámci habsburskej monarchie, okrem iného umožnil zrod Československej republiky (d’alej ČSR). Hoci si tento stav mnohí priami aktéri nechceli pripustit', čoskoro bolo jasné, že Trianonská mierová zmluva z júna 1920 potvrdzujúca hranice mad’arského štátu a okolitých štátov, sa 
neodškriepitel'ne zaradí $\mathrm{k}$ prelomovým historickým udalostiam strednej Európy. S vytýčením nových hraníc priamo súvisela skutočnost', že asi polovica etnických Mad'arov zostala nútene žit' mimo rámce Mad'arska. Rovnako ako Uhorsko aj nová Československá republika musela čelit' etnickým problémom. Počet obyvatel'stva mad’arskej národnosti v dôsledku prirodzeného návratu časti pomad'arčeného obyvatel'stva $\mathrm{k}$ pôvodnej slovenskej národnosti, ale aj asimilačnej politiky štátu a migrácie, v medzivojnových cenzoch postupne klesal. Už počas roku 1920 došlo k markantnej migračnej vlne príslušníkov mad’arskej menšiny. Pre existenčné problémy a pre nezloženie slubu vernosti novej republike ju muselo opustit' 105 tisíc Mad'arov. Československé úrady odmietli udelit' vyše 40 tisícom Mad'arov štátne občianstvo (Sprocha et al., 2016: 143).

Mad'arské obyvatel'stvo rozhodnutie mocností o tom, že sa stalo menšinou s nejasnou perspektívou, zväčša chápalo ako krivdu. Vniknutý stav vnímali ako národnú tragédiu. Dôsledkom toho bolo, že sa stotožňovalo $\mathrm{s}$ požiadavkami mad’arských politických reprezentácií na revíziu hraníc. Tým sa mad’arská menšina dostávala do konfliktu s integritou štátu, v ktorom žila. O utíšenie situácie sa navyše cielene neusilovala ani štátna moc medzivojnovej ČSR, ktorej propaganda účelovo akcentovala, že rozchod s Rakúsko-Uhorskom neznamená rozchod s vlast’ou, ale s macošským nepriatel'ským štátnym útvarom (Arpas, 2017: 235).

Životné podmienky života a identita mad'arskej menšiny boli v medzivojnovom Československu upravené právnymi normami, ktoré zaručovali občiansku rovnoprávnost', politickú sebarealizáciu, školské vzdelávanie a kultúrny život $\mathrm{v}$ materinskom jazyku, pričom štát preferoval občianske princípy. Na základe jazykového zákona z 29. februára 1920 sa na školách pre príslušníkov národnostných menšín vyučovalo $\mathrm{v}$ ich jazyku, rovnako aj ich kultúrne inštitúcie sa spravovali v jazyku menšiny. Mad’arská menšina tieto práva plne a intenzívne využívala. Problémy vo vzt’ahu $\mathrm{k}$ mad’arskej menšine sa prejavili predovšetkým v hospodárskej a sociálnej oblasti. Ako neprávost' vnímali mad’arskí obyvatelia tiež personálnu politiku vo verejnej správe, otázku štátnej príslušnosti či zákaz používania vlastných národných symbolov (Attila, 2010: 313).

Predstavitelia mad’arskej menšiny v Československu zareagovali na sled udalostí - rovnako ako budapeštianske vlády - presadzovaním iredentistickej koncepcie vzt'ahu voči republike. Po nástupe Hitlera $\mathrm{k}$ moci $\mathrm{v}$ Nemecku sa Budapešt' pridala $\mathrm{k}$ jeho stratégii smerujúcej $\mathrm{k}$ zlikvidovaniu „neželanej“ republiky. V jednotnom postupe s nemeckými nacistami mad'arská vláda zahalila svoje územné požiadavky do starostlivosti materského národa o mad'arskú menšinu (Deak, 1990 : 21). Vzhl'adom na vojenskú slabost' Mad'arska ostal jedinou možnost’ou boj na poli diplomacie podporovaný diverznými činmi. Mocenské zmeny $\mathrm{v}$ Európe $\mathrm{z}$ konca tridsiatych rokov umožnili Hitlerovi vyriešit' „československú otázku“ a ovplyvnili aj podobu slovensko-mad’arských vzt’ahov. Cesta k revízii hraníc sa Mad'arsku otvorila po mníchovskom diktáte. Na základe rozhodnutia, podpísaného 2. novembra 1938 vo Viedni, Slovensko do ôsmich dní 
odstúpilo územie s rozlohou vyše 10 tisíc $\mathrm{km}^{2}{ }^{1}$ Viedenská arbitráž bola jednou z klúčcových udalostí konca 30-tych rokov vo vývoji strednej Európy (Adam, 1965 : 881-882). Arbitrážne rozhodnutie malo vážne dopady nielen na destabilizáciu slovensko-mad’arských vzt’ahov, ale aj na formovanie sa politického režimu na Slovensku, pretože potvrdilo Mad'arsko v pozícii celospoločenského nepriatel'a Slovákov, čo zároveň umožňovalo posilnit' totalitné prvky l’udáckeho režimu.

\section{Trianon v novších stredoškolských učebniciach na Slovensku}

$\mathrm{Na}$ vytváraní rozmanitých vnímaní do značnej miery participovalo a zaiste i bude participovat' školské vzdelávanie. Trianon, Viedenská arbitráž rovnako aj d’alšie problematické okruhy slovensko-mad'arských vzt’ahov, možno zaradit' $\mathrm{v}$ dejepisnom vyučovaní medzi náročné témy (Benes, 2015: 289-326). Ked’že základnou studnicou vedomostí sú textové pomôcky, je na mieste pozriet' sa bližšie, ako je tomu v prípade vzt’ahu k skúmanej téme $\mathrm{v}$ učebniciach, z ktorých sa na Slovensku postupne učilo. Funkciu a význam učebníc dejepisu vo vzt’ahu $\mathrm{k}$ žiakom i pedagógom vytýčili v minulosti viacerí poprední didaktici. ${ }^{2}$ Štúdia mad’arského literárneho historika pôsobiaceho na Slovensku Barnabáša Vajdu o téme Trianonu v československých učebniciach dejepisu, poukazuje, že v učebniciach prvej ČSR sa dôraz kládol na príbeh úspechu Československa po prvej svetovej vojne, a hoci téma Trianonu nepatrila medzi dominantné témy, bola prítomná s tendenciou vytvorenia pozitívneho predobrazu budúcnosti Mad’arov v tomto štáte. Po roku 1945 bol Trianon v Československu - rovnako ako v Kádarovom Mad’arsku - tabuizovaný, takže žiaci vyrastajúci v tomto období nemali jasno v tejto otázke (rovnako ani v otázke vzniku a charakteru prvej ČSR (Vajda, 2013: 194). Rok 1989 priniesol pomalé zlepšenie, pričom ale - ako dokazuje aj Vajda, je problémom, že väčšina slovenských učebníc bola poznačená etnocentrizmom, ktorý neprikladá vel'kú pozornost' tým, ktorí Trianonom niečo stratili (Vajda 2013: 200). Príkladom je text jednej z prvých učebníc pre stredné školy autorského dua Dušan Kováč - Lubomír Lipták z roku 1992, ktorý je delený do 13 kapitol, pričom zvolená téma sa nachádza

\footnotetext{
${ }^{1}$ Pod mad’arskú správu pripadli také mestá ako Nové Zámky, Levice, Šahy, Lučenec, Rimavská Sobota, Rožňava a Košice, ktorých stratu znášali Slováci vel'mi t’ažko. BYSTRICKÝ, Valerián. Slovenská autonómia za druhej republiky a vznik Slovenského štátu. In FERENČUHOVÁ, Bohumila - ZEMKO, Milan (eds.). Slovensko v 20. storočí. V medzivojnovom Československu 1918 - 1938. Bratislava: Veda, 2012, s. 482-483.

${ }^{2} \mathrm{~V}$ kontexte nami sledovanej témy si možno vypomôct' definíciou podl’a slovenskej historičky Slávky Otčenášovej: „Učebnice vo vel'kej miere prispievajú $k$ formovaniu neraz vágnych, no trvácnych dojmov o identite a histórii národa a mnoho ludí si tieto dojmy uchováva aj potom, ako zabudnú všetky naučené historické fakty. To znamená, že sú vel'mi dôležitou verziou výkladu toho, kto sme a ako sme sa stali tým, kým sme. Sú súčast’ou oficiálnej historiografie a sú spol'ahlivým nástrojom i reflexiou šírenia oficiálneho kánonu a politickej indoktrinácie." OTČENÁŠOVÁ, Slávka. Schválená minulost'. Kolektívna identita v československých a slovenských učebniciach dejepisu (1918 - 1989). Košice: Univerzita Pavla Jozefa Šafárika, 2010, s. 130. Autorka v tomto diele na stranách $61-64,92-94$ a $123-125$ ponúka aj analýzu obrazu Mad'arov v československých a slovenských učebniciach. OTČENÁŠOVÁ, Slávka. Schválená minulost'. Kolektívna identita v československých a slovenských učebniciach dejepisu (1918 - 1989). Košice: Univerzita Pavla Jozefa Šafárika, 2010, s. 130. Autorka v tomto diele na stranách 61 - 64, 92 - 94 a 123 - 125 ponúka aj analýzu obrazu Mad’arov v československých a slovenských učebniciach.
}

Slavonic Pedagogical Studies Journal, eISSN 1339-9055, ISSN 1339-8660, Volume 9 Issue 2, 2020 
v tematickom celku IV. Medzinárodné postavenie Česko-Slovenska medzi dvoma vojnami, v kapitole Vznik versaillského systému (Kovac et al., 1992: 27-28). Autori v nej približujú tvorbu mierových zmlúv, vrátane Trianonu. $\mathrm{Na}$ ôsmich riadkoch poukazuje na zdíhavé rokovanie s Mad'arskom, na obštrukcie, revizionistické požiadavky, ktoré ale nie sú vôbec vysvetlené. Uvádza dátum uzavretia zmluvy 4. júna 1920, podl'a ktorej muselo Mad'arsko uznat' nezávislost' nástupníckych štátov (Kovac et al., 1992 : 35).

Po roku 2005 vznikli v krátkom čase dve učebnice dejepisu pre tretí ročník gymnáziii. ${ }^{3}$ Učebnica $\mathrm{z}$ roku 2005, ktorú zostavili Alena Bartlová a Róbert Letz, obsahuje šest' tematických celkov, pričom sledovanej otázke sa venuje tematický celok Slovensko v Československej republike s témou Slovensko vstupuje do ČSR (Bartlova, 2005 : 29).

Autorka učiva Alena Bartlová spomína tému len okrajovo. $\mathrm{S}$ Trianonom sa stretneme na strane $35 \mathrm{v}$ stručnom textovom úryvku, ktorý opakovane zmieňuje snahu pripojit' diplomatickými i nediplomatickými krokmi k Mad’arsku slovenské územia, ktoré mad’arská armáda obsadila v máji 1919 (dve pätiny územia). Pod medzinárodným tlakom sa cudzia armáda stiahla za určenú hraničnú čiaru. Definitívne sa otázka hraníc uzavrela zmluvou zo 4. júna 1920 v Trianone. Text uvádza aj hraničné problémy s Pol'skom (Bartlova, 2005: 35). Slovníček je spojený s témou - od pojmu decentralizácia, až po pojmy ako integrita, zvrchovanost', suverenita. Otázky a úlohy sa venujú nadobúdaniu praktických skúseností vo forme vyhl'adávania prvých poslancov zo Slovenska, resp. ministrov pre správu Slovenska.

Viedenská arbitráž sa nachádza $\mathrm{v}$ rovnakom celku, avšak v téme nazvanej Slovensko pod tlakom rozbúrenej Európy (pp. 65-66). Text stručne poukazuje na stretnutie ministrov zahraničných vecí Nemecka a Talianska za formálnej účasti zástupcov Československa a mad’arskej vládnej delegácie. Text dopíña farebná mapa znázorňujúca územné straty v prospech Pol'ska a Mad'arska. Učebnica jasne vyčísluje straty v podobe obyvatel'ov, ornej pôdy, priemyselnej výroby s presným menovaním častí mestských aglomerácií, o ktoré ČSR prišla - Košice, Rožňava, Levice, Lučenec, Rimavská Sobota ai. $\mathrm{V}$ texte sa nespomína, ako sa nakladalo s obyvatel'stvom na arbitrážnom teritóriu, ktoré hlavne slovenská čast' využila na zbavenie sa časti úradníctva českej národnosti. Arbitrážnemu územiu sa venuje následne len úryvok $Z$ hlbín archívov, konkrétne z diela Prehl'ad polnohospodárskeho vývoja na Slovensku v rokoch 1918 - 1945 (pp. 309-310). Ukážka poukazuje na skutočnost', že na dotknutom území ležali predovšetkým produkčné oblasti pre tabak papriku, vinohrady, strukoviny ai. Novinkou je odporúčanie na oboznámenie sa s dielom Ladislava Deáka Viedenská arbitráž z roku 1993 (Bartlova, 2005 : pp. 65-66).

Problém slovensko-mad'arských vzt'ahov z obdobia 1939 - 1945 rezonoval v osobitnej kapitole - v tematickom celku Slovenská republika a v téme Slovensko - nový štát na mape Európy. Treba konštatovat', že autor Róbert Letz sa vcelku vyvážene popasoval s celým súborom kontroverzných

\footnotetext{
${ }^{3}$ Obe učebnice uvádzajú, že boli zaradené do zoznamu učebníc, avšak bez udania doby ich platnosti, hoci učebnice vydávané po tomto období už schval'ovaciu doložku s rokmi platnosti (5 rokov) štandardne mali.
} 
otázok, počnúc tzv. Malou vojnou (p. 78), cez postavenie národností na Slovensku a v Mad'arsku až po zásadu reciprocity (pp. 89-95), pričom tému ilustroval historickými dokumentmi.

Problematika slovensko-mad'arských vzt'ahov sa v medzivojnovom období týkala aj celoeurópskych kontextov. Trianonom sa preto zaoberala aj učebnica Dejepis pre 3. ročník gymnázií. Svetové dejiny z roku 2006 od Daniely Kodajovej a Márie Tonkovej. Učebnicu tvoria štyri tematické celky. Trianonu je venovaná téma Mierové usporiadanie sveta - princípy a realita, v tematickom celku Svet na križovatke (Kodajova et al., 2006 : 32 ).

Zameriava sa chronologicky na udalosti na mierovej konferencii, podpisu jednotlivých zmlúv, pričom Trianon interpretuje ako zmluvu, ktorá sa rodila t’ažko. Zdôrazňuje udalosti po zániku Rakúsko-Uhorskej monarchie, napätú vnútropolitickú situáciu, vznik Mad’arskej republiky rád a podpis zmlúv z júna 1920 len pod tlakom medzinárodnej situácie. V časti Z hlbín archívov je dôraz kladený na prejavy významných politikov ako Raymond Poincaré a David Lloyd George, nasleduje slovník historika s pojmami priamo súvisiacimi s povojnovou situáciou ako multietnickost', reparácie, garancia, integrita ai. Záverečné otázky a úlohy sa rovnako sústred’ujú na multietnickost', napríklad: „Aké reformy by podla Vás zachránili vel'ké multietnické monarchie pred rozpadnutím?" Študenti sa majú vžit' aj do úlohy expertov a pokúsit' sa stanovit' hranice nových štátov. Majú sa pokúsit' odpovedat' na otázku, aké kritéria by pri ich vymeriavaní uplatnili (Kodajová et al., 2006 : 36). Situáciu z konca 30. rokov autorka Mária Tonková rozpracovala v učive Smutné dni predvojnovej krízy a prvé ohniská vojny. Na rozdiel od Mníchovskej dohody tu nenájdeme žiadnu zmienku o Viedenskej arbitráži (Kodajova et al., 2006 : 96).

V súlade $\mathrm{s}$ inovovaným Školským vzdelávacím programom už novšie učebnice uvádzajú, že sú schválené na 5 rokov od vydania. Konkrétne ide o učebnicu od autorov Roberta Letza, Márie Tonkovej a Anny Bockovej z roku 2013. Celkovo je rozdelená na 10 tematických celkov, pričom Trianon sa nachádza v celku Prvý celosvetový vojnový konflikt v rámci témy Versaillské usporiadanie Európy ( Letz et al., 2013: 27). Text uvádza, že zmluva bola podpísaná až neskoršie kvôli vnútorným komplikáciám v krajine v podobe vyhlásenia Mad'arskej republiky rád. Podrobnostiam a obsahu zmluvy sa pozornost' nevenuje (Letz et al., 2013: 30).

Kapitola d’alej pokračuje v otázke národnostných menšín a vzniku Spoločnosti národov. Možno konštatovat', že Trianonu - na rozdiel od textu súvisiaceho s neskorším vývojom, ktorý vyvrcholil Viedenskou arbitrážou z 30. rokov 20. storočia, nie je venovaná dostatočná pozornost'.

Viedenská arbitráž je zaradená do tematického celku Slovenská republika 1939 - 1945 v rámci témy Rozhoduje sa o osude Česko-slovenskej republiky. Text sa začína už neúspešnými rokovaniami v Komárne z októbra 1938, pričom $\mathrm{v}$ dôsledku nezdaru došlo $\mathrm{k}$ Viedenskej arbitráži za prítomnosti zástupcov Nemecka a Talianska. Učebnica jednoznačne poukazuje na stratu 21 \% územia Slovenska. Doplnkový text presne menuje mestá ktoré pripadli Mad’arsku ako Senec, Galanta, Dunajská Streda, Nové Zámky, Vráble, Šurany, Levice, Lučenec, Fil'akovo, Rimavská Sobota, Rožňava, Košice, Vel'ké Kapušany. Upozorňuje aj na infraštruktúrny problém v podobe 
prerušenia dopravného spojenia medzi Slovenskom a Podkarpatskou Rusou. Text, ktorý bol oproti predchádzajúcim učebným publikáciám pridaný, uvádza, že došlo $\mathrm{k}$ prepúśstaniu zamestnancov slovenskej národnosti z radov učitel'ov, úradníkov, poštárov, železničiarov na pričlenenom území ako i k prenasledovaniu Slovákov. Symbolom sa stala Mária Kokošová, ktorú zastrelili na Vianoce 1938 mad'arskí žandári v Šuranoch. Doplnená bola aj čast' Z historických prameňov, kde sa priamo nachádza ukážka z rokovaní z Komárna z októbra 1938. Na danú stat' nadväzujú otázky - po prečítaní ukážky študenti následne majú zodpovedat', aké argumenty a stanoviská mali delegácie. V záverečnej časti (Kontrolujeme a prehlbujeme vedomosti) je úlohou študentov uviest' súvislost' medzi Mníchovskou dohodou a Viedenskou arbitrážou ako aj jej dôsledky. Slovník vysvetl'uje obsah pojmu arbitráž (Letz et al., 2013 : 140).

Žiadna $\mathrm{z}$ vyššie uvedených učebníc nemá metodický pokyn ani pracovný list (hoci pre prvý ročník gymnázií pracovný list publikovaný bol), rovnako to platí aj o absentujúcej dejepisnej čítanke.

\section{Učebnice pre základné školy na Slovensku}

Náplň učebníc nie je z pohl’adu skúmanej problematiky optimálna ani na druhom stupni základných škôl, resp. na osemročných gymnáziách. Učebnica pre základné školy Dejepis 4: Slovensko v novom storoči (prvé vydanie z roku 1996), ktorá zahŕňa obdobie rokov 1914 až 1993, približuje územné konštituovanie ČSR. Hoci sa v texte píše o problémoch s vytýčením hraníc, so začleňovaním Slovenska do novej republiky (pp. 16-17), ako aj o problematike národnostných menín v medzivojnovom období (pp. 28-29), sumárne možno poznamenat', že učebnica nepodala žiakom žiadnu informáciu nielen o Trianone, ale ani o Benešových dekrétoch či o reslovakizácii. Absencia niektorých dôležitých informácií je jej nepochopitel'ným hendikepom. Na druhej strane je detailnejšie vdvoch učivách Mračná nad Česko-Slovenskom a Od autonómie k samostatnosti charakterizovaná Viedenská arbitráž. Špeciálna pozornost' je venovaná postaveniu Slovákov na arbitrážnom teritóriu, ktoré nazýva „okupovaným územím“(Kovac et al., 1996, 2000 a 2003: 37, 40). Sledovanú problematiku dotvárala učebnica svetových dejín pre 9. ročník, ktorej autorka Herta Tkadlečková píše o vzniku nástupníckych štátoch po tom, čo sa Karol Habsburský vzdal uhorského trónu, a národnostných menšinách v nich (Tkadleckova et al., 1995: 16). Ďalšou učebnicou, pri ktorej sa zastavíme, je Dejepis pre 9. ročník základných škôl a 4. ročník gymnázia s osemročným štúdiom z roku 2012. Učebnica obsahuje tematický celok Prvá svetová vojna, kde sa v téme Ako sa rodil mier zameriava pozornost' mierovej konferencii ako takej, t.j. všeobecne utváraniu mierových zmlúv. Problematike stanovenia hraníc, bez uvedenia Trianonskej zmluvy, je poskytnutý priestor v téme Nové štáty na mape Európy ${ }^{4}$ (Kratochvil et al., 2012: 24-25 a 30). Väčšej pozornosti je v tejto učebnici venovaná otázka Viedenskej arbitráže (pp. 64-65), kde sa arbitráž uvádza ako priamy dôsledok

\footnotetext{
${ }^{4}$ Pozitívnym doplnkom tejto učebnice dejepisu sa neskôr stal pracovný list KOLEKTÍV autorov. Hravý dejepis 9. Bratislava: Taktik, 2016, 76 s.
} 
Mníchovskej dohody. Slovensko stratilo pätinu územia, pričom na zabratom území došlo k prudkej strate životnej úrovne a prudkému národnostnému útlaku. Informácie sú doplnené o Pol'sko, pod ktorého správu prešlo $226 \mathrm{~km}^{2}$ územia na Orave a Spiši. Text doplńa aj mapa s farebnými vyznačeniami odstúpených území po Viedenskej arbitráži. V slovníčku je slovo arbitráž. Jednou z úloh, ktoré má žiak ovládat', je charakteristika dôsledkov Viedenskej arbitráže pre Slovensko. Ikonický materiál je doplnený fotografiou, na ktorej vyhlásenie arbitráže číta minister zahraničných vecí Tretej ríše Joachim Ribbentrop (Kratochvil et al. 2012: 64-65)V prípade učebníc pre školy s mad'arským vyučovacím jazykom platila na Slovensku prax, že šlo o preklady slovenských učebníc s určitými doplnkami. Takýto prístup zmenila až séria mad'arských učebníc autorskej dvojice László Kovács - Attila Simon, ktorá ponúkla aj problematiku Trianonu v multiperspektívnom kontexte (Kovacs et al., 2000).

\section{Sonda do najnovších učebníc v Českej republike}

Ked'že v prípade Trianonskej tematiky šlo o problém spoločného štátu, určitým vzorom, ktorým sa možno v rámci didaktiky dejepisu inšpirovat', je dejepisné vyučovanie v Českej republike. Viditel'ný rozdiel vidiet' nielen v odlišnej hodinovej dotácii dejepisu pre stredné školy týždenne, ale aj v inej učebnicovej politike. Príkladné sú najmä české učebnice pre stredné školy z vydavatel'stva Didaktis. Menované vydavatel'stvo napĺn̆a aktuálne didaktické trendy, a to nielen učebnicou z roku 2014 prepojenou s čítankou a geografickou mapou, ale aj s pracovnými listom a metodickým pokynom. Učebnica, zostavená kolektívom autorov pod vedením Jana Dvořáka, je delená do 5 tematických celkov, ktorú doplńa samostatná Historická čítanka s dejepisnými mapami ku každému celku zvlášt'. Problematika Trianonskej zmluvy sa nachádza v tematickom celku Prví světová válka a nová Evropy pod témou Mírové smlouvy a nová mapa Evropy (Dvorak et al., 2014 : 27). V samostatnom odseku - Trianonská dohoda, mad'arský revizionizmus a Malá dohoda - poukazuje na skutočnost', že zmluva neznamenala pre Mad'arsko len územné straty, ale mala aj ekonomické dopady, čo viedlo k snahám o revíziu dohody. Spomína sa vznik Republiky rád na čele s Bélom Kunom. Autori nezabúdajú na skutočnost', že podpisom zmlúv nepokoje na hraniciach mad'arsko-československých neustali a dochádzalo k útokom na predstavitel'ov československej správy (menujú konkrétne prípady z rokov 1921,1922) (Dvorak et al., 2014: 28).

Podrobnostiam zmluvy či jej okolnostiam sa vel'a pozornosti nevenuje (Dvorak et al., 2014: 66). Učebnicu dopĺn̆a pracovný list od rovnakého autorského zloženia, ktorý k téme Trianonu obsahuje cvičenia na strane 22 . Cvičenia vo všeobecnosti rozvíjajú analytické myslenie, pričom pre Trianon sú vymedzené okrem použitia karikatúr dve cvičenia. Prvé z nich, cvičenie č. 9 , sa sústred'uje na mad'arské národnostné požiadavky. Otázky, na ktoré majú študenti odpovedat', ich odkazujú na modelovú situáciu, pri ktorej si majú predstavit', že by Mad'arsko vyšlo z mierových rokovaní bez územných strát. Následne majú diskutovat', za akých okolností by k takej situácii mohlo

dôjst' a aké by malo dôsledky pre politickú situáciu v strednej Európe (Dvorak et al., 2014 : 22). 
Nasledovné cvičenie sa zameriava na praktické argumenty - žiaci majú doplnit' do dvoch kategórii politické príčiny a územno-politické príciny spojené s mad'arským revizionizmom. ${ }^{5}$ Doplnením učebných pomôcok je sprievodca pre učitel'a, v ktorom sa otázka Trianonu preberá na strane 47. Prekvapivo učebnica, ani jej čítanková čast' neprináša ani jeden úryvok Trianonskej mierovej zmluvy, ani nevysvetl'uje bližšie jej význam s ohl'adom na stanovenie hraníc.

\section{Trianon v historiografii na Slovensku}

S didaktikou dejepisu sú pupočnou šnúrou previazané výsledky historickej vedy. Doterajší výskum slovensko-mad'arských vzt’ahov v 20. storočí sa na Slovensku sústredil predovšetkým na skúmanie počiatkov nového údelu, teda podmienok jej života v medzivojnovom Československu. Pokial' ide o obdobie po Viedenskej arbitráži v roku 1938, pozornost' slovenskej i mad’arskej historiografie $\mathrm{v}$ rámci tejto turbulentnej fázy sa z dôvodu niekol'konásobného zníženia početnosti mad'arskej menšiny obracala len na niektoré parciálne otázky, napríklad medzištátne slovenskomad'arské vzt’ahy či problematiku vtedajšej politickej reprezentácie na čele s lídrom menšiny Jánosom Esterházym. Určitým vzorom je po kvalitatívnej a kvantitatívnej stránke pomerne dobre spracovaná etapa slovenskomad'arskej relácie po druhej svetovej vojne (Vadkerty, 2002).

Práve na Trianone, ktorý zostáva gordickým uzlom vztahov Mad'arska so svojimi susedmi, môžeme jasne vidiet', ako sa tá istá udalost' môže interpretovat' historiografiami rozlične. Napriek tomu, že Trianon je klúčovým medzníkom zakomponovaným nielen $\mathrm{v}$ hodnoteniach slovenskomad'arských vzt’ahov, ale aj pri štúdiu slovenského národného príbehu ako takého, v slovenskej (rovnako aj českej) historickej spisbe stál na okraji centra pozornosti. Tak exponovaný medzník ako Trianon si ale zaslúži maximálnu pozornost' historikov, ktorí môžu skúmat' rôzne aspekty, od rozpadu a vzniku štátov, cez otázky etnicity až po historickú pamät'. $\mathrm{V}$ porovnaní s mad’arskou produkciou nemožno objem vedeckých prác z pera slovenských a českých historikov, ktoré sa problematiky Trianonu priamo alebo čiastočne dotýkali, hodnotit' priaznivo. Napriek tomu treba poznamenat', že za posledných 30 rokov vyšlo viacero štúdií a monografií, ktoré sa touto témou bližšie zapodievali. Takými boli napríklad práce Mariána Hronského, Ladislava Deáka, Milana Krajčoviča, Bohumily Ferenčuhovej, Petra Švorca, Milana Olejníka ai., z mladšej generácie bádatel'ov Miroslava Michelu, Lászlóa Vörösa, Antona Hruboňa a d’alších. ${ }^{6}$ Analýzu Trianonu v slovenskej historickej spisbe bližšie načrtol popredný slovenský historik Štefan Šutaj vo svojej štúdii zverejnenej v spomínanom zborníku „Rozpad Uhorska a Trianonská mierová zmluva“ z roku 2013. Vyplýva z nej potvrdenie faktu, že väššina slovenských historikov považuje existenciu Uhorska v situácii, v akej sa nachádzalo pred rokom 1914, za neudržatel'nú. O jeho zachovanie národy Uhorska - okrem mad'arského -

\footnotetext{
${ }^{5}$ Viedenská arbitráž je na strane 56, konkrétne sa jej venujú cvičenia č. 9. Žiak má v texte nájst' faktické chyby a opravit' ich.

${ }^{6} \mathrm{Z}$ českých historikov možno spomenút' práce Jaroslava Valentu, Evy Irmanovej, Jindřicha Dejmeka či Andreja Tótha.
} 
nemali záujem, lebo im neboli ponúknuté rovnoprávne a demokratické podmienky pre ich existenciu. Ich politické elity sa podiel'ali na koncipovaní nových možností, ktoré boli atraktívnejšie a výhodnejšie z národného aj ekonomického aspektu ako alternatívy ponúkané v čase ukončovania prvej svetovej vojny mad’arskými reprezentáciami (Sutaj, 2013: 114). Je potrebné doplnit', že dnes už na Slovensku existujú kritické práce o uhorských dejinách, ktoré ako dôvod narušenia koexistencie viacerých národov v dobe moderného nacionalizmu $\mathrm{v}$ krajine vidia $\mathrm{v}$ nepochopení, necitlivosti a antagonizmom na obidvoch (väčšinovej mad’arskej i národnostných) stranách (Konya et al., 2014 : 758-759).

\section{Na margo východísk ...}

Analýza tohto stavu prináša viacero zistení a poučení. Dôvodom nevyhovujúceho stavu je do vel'kej miery opomínanie didaktiky dejepisu na Slovensku a všeobecné podceňovanie významu výučby dejepisu, ktoré má za následok znižovanie jej hodinovej dotácie. Autori učebných médií i z týchto príčin zväčša priorizujú politické dejiny. Na škodu je, že hlbšej pozornosti tak unikajú sociálne dejiny či dejiny každodennosti, máme tiež poskromné poznatky o Poliakoch, Ukrajincoch, Rusínoch, Čechoch i o Mad'aroch. Pritom perspektíva, akým spôsobom preberané učivo a učebnú látku v tomto smere obohatit', je v hl'adaní cesty $\mathrm{k}$ prekonávaniu konfliktov (často politicky živených) skrz precíznejšie a vecné poznanie histórie. Rozhodujúce sporné otázky, na ktoré sa bude potrebné sústredit', definoval Marián Hronský: 1. interpretácia charakteru, príčin a dôsledkov historického procesu rozpadu Uhorska, 2. hodnotenie podielu národno-emancipačných hnutí a národných programov na definitívne povojnové usporiadanie stredovýchodnej Európy, 3. rozdielny prístup $\mathrm{k}$ úlohe vít'azných vel'mocí pri rozhodovaní o vzniku nových národných štátov a $\mathrm{k}$ rokovaniam mierovej konferencie (Hronsky, 2011: 10).

Miroslav Michela upozorňuje, že historická obec sa profiluje aj na verejnosti, ked’že $\mathrm{k}$ jej zviditel'neniu dochádza najmä prostredníctvom rôznych ideologicky prezentovaných káuz so silným emocionálnym nábojom. Avšak v nich sa do vel'kej miery len dookola opakujú tie isté argumenty a interpretačné vzorce, ktoré sa niekedy už viac podobajú mytologickým naráciám a zaklínadlám, ako snahám o racionálnu rekonštrukciu minulosti (Michela, $2008: 11$ ).

$\mathrm{Na}$ druhej strane viacerí autori varujú, že opomínanie témy v školskej výuke dejepisu prispieva ku vzniku negatívnych historických mýtov a nevhodných stereotypov uvažovaní o historických udalostiach (Labischova, 2011 : 9). Nové pohl'ady, ktoré budú reflektovat' také priority ako kritérium l'udskosti a zodpovednosti človeka za celok, môžu do výučby dejepisu priniest' detailnejší regionálny výskum, resp. výskum každodennosti a môžu tak dokreslit' mozaiku poznatkov nielen v rámci skúmania slovenskomad'arských vzt'ahov, ale aj v rámci skúmania dejín medzivojnovej ČSR a Slovenskej republiky. Tie by mohli ponúknut' odpovede, do akej miery politické režimy v strednej Európe zasahovali a ovplyvňovali životy bežných menšinových občanov nielen $\mathrm{v}$ politickej sfére, ale aj v kultúrnej, výchovnej či sociálnej oblasti, aké podmienky mali minority pri zakladaní a pôsobení 
spolkov a novinových redakcií, pri používaní materinského jazyka v školstve, kultúre a pri náboženských obradoch. Inšpiratívne by mohli byt' aj zistenia na otázky, či a $\mathrm{v}$ akej forme prichádzalo $\mathrm{k}$ reštrikciám $\mathrm{v}$ programe výchovy a vzdelávania detí mad’arskej národnosti, aké kroky činila vtedajšia mad’arská spoločenská elita, aby postavenie súkmeňovcov zlepšila, ako podporovala mad'arské rodiny, aké nosné faktory vplývali na život menšiny a akú úlohu zohrávala propaganda.

Učebnice ako didaktické prostriedky majú v edukačnom procese kl'účovú pozíciu, za pozornost' stojí tiež väzba medzi učitel'om a učebnicou, resp. medzi učitel’om a preberanou látkou. Súdobá didaktika rozlišuje tri roviny existencie vzdelávacieho obsahu - subjektívnu, intersubjektívnu a objektívnu. Z pohl'adu prezentovanej problematiky je zrejme najdôležitejšia intersubjektívna rovina, t. j. interakcia medzi učitel’om a jeho žiakmi. V ich špecifickom priestore vznikajú varianty dvoch dejov: výkladu historických udalostí a interpretácie historických udalostí (Mares, 2017: 37).

Ovel’a kritickejšia práca so študentmi je potrebná aj na Slovensku, najmä na slovenských katedrách histórie, teda budúcimi učitel'mi dejepisu, ktorým treba ponúknut' aj otázky o podstate problému - prečo bola hranica spornou, ako bola vytýčená, aké dôsledky malo jej určenie, prečo problém pretrváva dodnes a pod. Malo by byt' štandardom, aby študenti pracovali na seminároch s rôznorodými menej známymi i neznámymi interpretáciami známych faktov. Potešitel'né je, že $v$ tejto oblasti vidiet' určité pozitívne tendencie (existujú vysokoškolské učebné texty $\mathrm{k}$ viacerým čiastkovým otázkam slovensko-mad’arských vzt’ahov, ktorých čast' vznikla zo vzájomnej odbornej spolupráce). ${ }^{7}$

\section{Záver}

Na Slovensku výskum, ktorý by sa zaoberal reálnou podobou školského vyučovania dejepisu u žiakov základných a stredných škôl aj študentov učitel'stva, je marginálny. Jeho obsahom by mal byt' vzt'ah k histórii, historickým stereotypom, hodnoteniu niektorých historických udalostí v minulosti, ako aj postoje k vybraným kontroverzným udalostiam (Mares, 2017: 36-56). Historiografia tvorí - rovnako ako v minulosti - aj dnes, $\mathrm{v}$ podmienkach súčasnej parlamentnej demokracie jeden $\mathrm{z}$ efektívnych nástrojov politiky pri pôsobení na spoločnost'. Ked’že pre politické aparáty nie je nezvyčajná inštrumentalizácia histórie a účelové ponechávanie priechodu emóciám, úlohou historickej vedy by okrem samotného výskumu malo byt' poukázanie na funkciu historiografie pri sledovaní zlomových a zároveň problematických oblastí našich dejín. Na druhej strane však politika nie vždy vie adekvátne ocenit' spoločenskú potrebu historiografie, ktorá ako veda má vhodné vlastné nástroje na tvorbu objektívneho systému poznatkov o minulosti. Minulost' Trianonu a jeho dôsledkov je nutné vždy skúmat' s realistickým prístupom $\mathrm{v}$ širšom kontexte, $\mathrm{t}$. j. nie ako izolovaný fenomén. Platí pri tom téza, že koncept národných dejín nie je jediný možný prístup $\mathrm{k}$

\footnotetext{
${ }^{7}$ Napríklad Gabzdilova, Sona. Školský systém na Slovensku v medzivojnovej Československej republike (1918 - 1938). Košice: Univerzita Pavla Jozefa Šafárika, 2014. PEKÁR, Martin. Dejiny Slovenska 1918 - 1945. Vysokoškolská učebnica. Košice: Univerzita Pavla Jozefa Šafárika, 2015.
} 
výskumu histórie, pričom ale osobitosti národných dejín historici nemôžu stratit' zo svojho zretel'a.

Odborná diskusia a poznatky sa za ideálnych podmienok zvyknú transformovat' do vyučovacieho procesu. Základný rámec vyučovania na Slovensku predstavuje Štátny vzdelávací program a samozrejme učebnice dejepisu pre základné i stredné školy. Vzhl’adom na to, že na Slovensku neexistuje otvorená učebnicová politika, pedagógovia si nemôžu vybrat' z viacerých edukačných materiálov tak, ako je to napríklad v susednej Českej republike. $^{8}$ Slovenskou realitou je vždy len jedna zostava učebníc pre dejepisné vyučovanie pre základné a stredné školy. Schvalované sú ministerstvom školstva pre príslušný ročník a typ školy, pričom aktuálne spájajú v každej z nich národné i svetové dejiny. ${ }^{9}$ Aj preto by učebnice mali v budúcej tvorbe reflektovat' najnovšie poznatky vedeckého bádania, dozaista $\mathrm{v}$ zjednodušenej podobe, ale napriek tomu podávajúce čo najkomplexnejší rozmanitý obraz o udalostiach a dejoch $\mathrm{v}$ minulosti uskutočňovaných vo svete, ako aj na Slovensku, aby dokázali plnohodnotne rozvíjat' a formovat' schopnosti žiakov (Duchovicova, et al., 2018 : 258-272).Zástupca mladšej generácie slovenskej historiografie Martin Pekár, ktorý analyzoval obraz Mad’arov v dejepisných učebniciach v rokoch 1989 - 2008, zhrnul, že v prípade gymnaziálnych učebníc je pohl'ad väčšiny autorov na národné dejiny stereotypný, povrchný, jednostranný, bez názorových alternatív a niekedy i alibistický (Pekár, 2008:198).

Aká by teda mala byt' úloha didaktiky dejepisu vodbúravaní stereotypov? Mnoho odborných pojednaní $\mathrm{k}$ tejto otázke smeruje $\mathrm{k}$ tomu, že v prvom rade by tvorcovia učebníc a následne ani učitelia nemali stereotypné prvky ignorovat', ale naopak, aktívne sa snažit' o ich odstránenie prostredníctvom riadneho uchopenia historickej témy, vrátane akceptovania názorovej plurality. Tento ciel' sa dá dosiahnut' len vtedy, ak nebudú tému „abstraktne“ obchádzat' či minimalizovat' poznatky (Duchovicova et al., 2019: 49-55).

\section{Pod'akovanie}

Táto práca vznikla s podporou Agentúry na podporu výskumu a vývoja na základe zmluvy č. APVV-15-0368“. Prax v centre odborovej didaktiky, odborová didaktika v Centre praktickej prípravy. Je aj čiastkovým výstupom projektov VEGA č. 1/0093/18 Od demokracie k autoritárstvu. Zmeny slovenskej spoločnosti počas autonómie (1938-1939) na príklade Ponitria.

\section{Bibliographic references}

\footnotetext{
${ }^{8}$ Problematike by pomohol aj vzdelávací metodický portál, plne funkčný v Českej republike rvp.cz, ktorý na Slovensku absentuje. Pomohol by prepojit' didaktické prístupy a metódy s najnovšími historiografickými poznatkami. Napomohol by (nielen) začínajúcim pedagógom plasticky uchopit tému, čím by sa zlepšil samotný výchovno-vzdelávací proces.

${ }^{9}$ Zhruba do roku 2010 boli na Slovensku k dispozícii pre každý ročník základných i stredných škôl dve samostatné učebnice dejepisu - jedna pre národné dejiny a druhá pre svetové dejiny. Slavonic Pedagogical Studies Journal, eISSN 1339-9055, ISSN 1339-8660, Volume 9 Issue 2, 2020
} 
ADAM, M. et al. 1965. Diplomaciai iratok Magyarorszag kulpolitikajahoz 1936 - 1945 II.: A Muncheni egyezmeny letrejotte es Magyarorszag kulpolitikaja 1936 - 1938. Budapest: Akademiai kiado, .

ATTILA, S. 2010. Vplyv statopravnych a politickych zmien z konca roka 1938 a zo zaciatku roka 1939 na postavenie madarskej mensiny (so zvlastnym zretelom na bratislavskych Madarov). In BYSTRICKY, Valerian - MICHELA, Miroslav - SCHVARC, Michal (eds.). Rozbitie alebo rozpad? Bratislava: Veda, pp. 313-323.

ARPAS, R. 2017. Prvky cyrilo-metodskej tradicie ako sucast Pribinovho odkazu? (Oslavy 110. vyrocia krestanstva $\mathrm{v}$ Ceskoslovensku). In Konstantinove listy, vol. 10, n. 1, pp. 233-240.

BARTLOVA, A. - LETZ, R. 2005. Dejepis pre 3. rocnik gymnazii. Bratislava: SPN

BENES, Z. - GRACOVA, B. 2015. Didaktika dejepisu: mezi socializaci jedince a jeho individualni vychovou. In STUCHLIKOVA, Iva - JANIK, Tomas (eds.). Oborove didaktiky: vyvoj - stav - perspektivy. Brno: Masarykova univerzita, pp. 289-326.

BYSTRICKY, V. 2012. Slovenska autonomia za druhej republiky a vznik Slovenskeho statu. In FERENCUHOVA, Bohumila - ZEMKO, Milan (eds.). Slovensko v 20. storoci. V medzivojnovom Ceskoslovensku 1918 - 1938. Bratislava: Veda, pp. 477-516.

CIERNA-LANTAYOVA, D. 1992. Podoby cesko-slovensko-madarskeho vztahu 1938-1949. Bratislava : Veda.

DEAK, L. 1990. Slovensko v politike Madarska v rokoch 1938 - 1939. Bratislava: Veda, 189 p.

DEAK, L. 1986. Zapas o strednu Europu 1933 - 1938. Bratislava: Veda.

DUCHOVICOVA, J. - FENYVESIOVA, L. 2019. Applying of strategies of critical and creative thinking by teachers according to the teaching subject and degree of education. In Ad Alta: Journal of Interdisciplinary Research vol. 9, n. 1, pp. 49-55.

DUCHOVICOVA, J. - KOLENAKOVA , R.S. 2018. Mental mapping strategy in educative process and the quality of pupil's learning performance In Xlinguae, vol. 11, n. 2 , pp. 258-272.

DVORAK, J. et al. 2014. Moderni dejiny pro stredni skoly. Praha: Didaktis.

DVORAK, J. et al.2014. Moderni dejiny pro stredni skoly. Pracovni sesit. Praha: Didaktis.

GABZDILOVA, S. et al. 2011.Vybrane aspekty postavenia madarskej minority na Slovensku v rokoch 1918 - 1929. Kosice: Spolocenskovedny ustav SAV.

GABZDILOVA, S. 2014. Skolsky system na Slovensku v medzivojnovej Ceskoslovenskej republike (1918 - 1938). Kosice: Univerzita Pavla Jozefa Safarika.

HRONSKY, M. 2011. Trianon. Vznik hranic Slovenska a problemy jeho bezpecnosti (1918 - 1920). Bratislava: Veda.

KODAJOVA, D. - TONKOVA, M. 2006. Dejepis pre 3. rocnik gymnazii. Svetove dejiny. Bratislava: SPN..

KOLEKTIV autorov.2016. Hravy dejepis 9. Bratislava: Taktik. KONYA, P. et al.2014. Dejiny Uhorska. Bratislava: Citadella. 
KRATOCHVIL, V. - KOVAC, D. - KAMENEC, I. - TKADLECKOVA, H. 2012. Dejepis pre 9. rocnik ZS a 4. rocnik gymnazia s osemrocnym studiom. Bratislava: SPN.

KOVAC, D. - KAMENEC, I. - KRATOCHVIL, V. 1998. Tortenelem 4. Szlovakia az uj evszazadban. Bratislava: Orbis Pictus Istropolitana.

KOVAC, D. - LIPTAK, L. 1992. Kapitoly z dejin pre stredne skoly. Bratislava: SPN .

KOVAC, D. - KAMENEC, I. - KRATOCHVIL, V. 1996. Dejepis 4. Slovensko v novom storoci : Ucebnica pre 9. rocnik zakladnych skol a pre 4. rocnik osemrocnych gymnazii. Bratislava: Orbis Pictus Istropolitana.

KOVACS, L. - SIMON, A. 2000. A magyar nep tortenete a 20. szazadban. Dunaszerdahely: Lilium Aurum.

LABISCHOVA, D. 2011. Klicove momenty a kontroverzni udalosti povalecne historie $\mathrm{v}$ historickem vedomi zaku, studentu a ucitelu (vysledky empirickeho vyzkumu. In Sbornik praci Pedagogike fakulty Masarykovy univerzity v Brne, roc. 25 , c. 2 , s. 9-25.

LETZ, R. - TONKOVA, M. - BOCKOVA, A. 2013. Dejepis pre 3. rocnik gymnazii a strednych skol. Bratislava: SPN.

LETZ, R.1995. Nacrt dejin Uhorska a Madarska. Bratislava: Polygrafia, 1995.

MARES, J. 2017. Eticka dilemata ucitelu dejepisu aneb jak vyucovat o kontroverznich obdobich dejin? In Historie - Otazky - Problemy, roc. 9, c. 2, s. 36-56.

MICHELA, M. 2018. Uhersko-madarske tradice. In HAJKOVA, Dagmar et al. Slava republice! Oficialni svatky a oslavy v mezivalecnem Ceskoslovensku. Praha: Nakladatelstvi Academia - Masarykuv ustav a Archiv AV CR, v. v. i., pp. 431-468.

OTCENASOVA, S. 2010. Schvalena minulost. Kolektivna identita v ceskoslovenskych a slovenskych ucebniciach dejepisu (1918 - 1989). Kosice: Univerzita Pavla Jozefa Safarika.

PEKAR, M. 2008. Madari a madarska mensina na Slovensku v slovenskych ucebniciach dejepisu po roku 1989. In SUTAJ, Stefan et al. Madarska mensina na Slovensku po roku 1989. Presov: Universum, pp. 184-199.

PEKAR, M. 2015. Dejiny Slovenska 1918 - 1945. Vysokoskolska ucebnica. Kosice: Univerzita Pavla Jozefa Safarika.

SPROCHA, B.- TISLIAR, P. 2012. Demograficky obraz Slovenska v scitaniach ludu 1919 - 1940. Brno: Tribun EU.

SPROCHA, B.- TISLIAR, P. 2016. Demograficky obraz Slovenska v scitaniach ludu 1938 - 1945. Bratislava: Muzeologia a kulturne dedicstvo, o.z.

SUTAJ, S. 1993. Madarska mensina na Slovensku v rokoch 1945 - 1948. Bratislava: Veda, 1993.

SUTAJ, S. 2013. Trianon v historickej pamati na Slovensku. In MICHELA, Miroslav - VOROS, Laszlo et al. Rozpad Uhorska a Trianonska mierova zmluva : K politikam pamati na Slovensku a v Madarsku. Bratislava: Historicky ustav SAV, pp. 115-130.

TKADLECKOVA, H. - KRATOCHVIL, V. 1995. Svet v novom storoci. Bratislava: Orbis Pictus Istropolitana. 
VADKERTY, K. 2002. Madarska otazka v Ceskoslovensku 1945 - 1948. Dekrety prezidenta Benesa a ich dosledky na deportacie a reslovakizaciu. Bratislava: Kalligram.

VAJDA, B. 2013. Trianonska problematika a (cesko)slovenske ucebnice dejepisu. In MICHELA, Miroslav - VOROS, Laszlo et al. Rozpad Uhorska a Trianonska mierova zmluva : $\mathrm{K}$ politikam pamati na Slovensku a $\mathrm{v}$ Madarsku. Bratislava: Historicky ustav SAV, pp. 185-201

Doc. PhDr. Martin Hetényi, PhD.

Department of History Faculty of Arts

Constantine the Philosopher University in Nitra

Hodžova 1

94901 Nitra,

Slovak Republic

mhetenyi@ukf.sk

Doc. PhDr. Adriana Kičková, PhD.

Department of History Faculty of Arts

Constantine the Philosopher University in Nitra

Hodžova 1

94901 Nitra,

Slovak Republic

akickova@ukf.sk 